\title{
Assessment of Trace Heavy Metals Contamination in the Tissues and Saliva of the Medicinal Leech Hirudinaria manillensis
}

\author{
Mohamed Alaama ${ }^{1, *}\left(\mathbb{D}\right.$, Abdualrahman Mohammed Abdualkader ${ }^{1}$, Abbas \\ Mohammad Ghawi ${ }^{2}$, Ahmed Merzouk ${ }^{3}$, Reem. S. Khalid ${ }^{1}$, A. B. M. Helaluddin ${ }^{1}$
}

${ }^{1}$ International Islamic University Malaysia (IIUM), Department of Pharmaceutical Chemistry, Kulliyyah of Pharmacy, Jalan Sulthan Ahmed Shah, Bander Indera Mahkota, 25200, Kuantan, Malaysia.

2International Islamic University Malaysia (IIUM), Department of Basic Medical Science, Kulliyyah of Pharmacy, Jalan Sulthan Ahmed Shah, Bander Indera Mahkota, 25200, Kuantan, Malaysia.

${ }^{3}$ Biopep Solutions Inc., Vancouver, BC Canada.

\section{How to cite}

Alaama, M., Abdualkader, A.M., Ghawi, A.M., Merzouk, A., Khalid, R.S., Helaluddin, A.B.M. (2021). Assessment of Trace Heavy Metals Contamination in the Tissues and Saliva of the Medicinal Leech Hirudinaria manillensis. Turkish Journal of Fisheries and Aquatic Sciences, 21, 225-231. http://doi.org/10.4194/1303-2712-v21_5_02

\section{Article History}

Received 18 September 2020

Accepted 14 February 2021

First Online 17 February 2021

Corresponding Author

Tel.: +905525568757

E-mail: hass83pharm@gmail.com

\section{Keywords}

Leeches

Heavy metals

Leeches' saliva extract

ICP-MS

\begin{abstract}
Concentrations of heavy metals (HMs) in the tissues and saliva extracts of leeches (Hirudinaria manillensis) collected from Cheneh Lake, Terengganu, Malaysia were investigated. Concentrations of HMs like Cadmium (Cd), Chromium (Cr), Iron (Fe), Manganese ( $\mathrm{Mn})$, Nickel (Ni), Lead (Pb), Selenium (Se) and Zinc $(\mathrm{Zn})$ were revealed by utilising Inductively Coupled Plasma Mass Spectroscopy (ICP-MS). Nearly all the examined HMs concentrations in the lake water were noted to be higher compared to the Maximum Permissible Limits (MPL) as per Interim National Water Quality Standards for Malaysia (INWQS). Moreover, traces of HMs were discovered in tissues and saliva extracts of leeches. Such quantities may pose a health hazard to the patients upon an instant application of leeches on their skin. In this work, a novel technique was presented to decrease the level of metals in leech saliva by espousing a frequent washing process involving deionized or non-chlorinated water for three weeks. This process was extremely effectual in considerably decreasing $\mathrm{HMs}$ concentrations $(\mathrm{P}<0.05$ ), particularly $\mathrm{Cd}$ level (up to $99.7 \%$ ) in saliva and $\mathrm{Pb}$ level (up to $92.38 \%$ ) in tissues. Thus, a constant washing process might aid in harmless utilization of leeches for different conventional biomedical practices.
\end{abstract}

\section{Introduction}

The existence of HMs is commonly observed in stagnant water, ponds, and lakes, particularly in tropical regions such as Malaysia (Basheer et al, 2017; Yunus et al., 2020). Such HM contaminations affect the environment and public wellbeing (EPA, 2009). The traces of $\mathrm{HMs}$ in the environment and their likely impacts on living organisms, drinking water, and food nutrients have been analysed earlier (Karadede \& Ünlü, 2000; Masindi \& Muedi, 2018; Mishra et al., 2019). In Malaysia, many research works have been undertaken to offer a better comprehension of HMs contaminations in food, drinking water, and conventional medical herbs
(Ahmad et al., 2018; Sulaiman et al., 2016; ShuhaimiOthman, 2009).

Leeches have been utilised in traditional medications because of the effective impact of their bite which is said to comprise bioactive compounds (Alaama et al., 2011). They are believed to cure an extensive gamut of ailments like skin disorders, arthritis, eye complications and plastic surgery (Abdualkader et al., 2013; Singh \& Rajoria, 2019; Porshinsky et al., 2011). The medicinal leech (Hirudo medicinalis) was approved by FDA as a medical device for mechanically alleviating venous congestion through anticoagulants to the site of congestion (Rados, 2004). Many species of leeches have been conventionally utilised in Malaysia for medical 
cure (Sivachandran, et al., 2013). Notably, most of the leeches utilised in conventional medicine are fetched from their natural habitats such as ponds. Tropical climates experience a considerable amount of rain, and coastal developmental undertakings cause substantial HMs land to run-off and ultimately sink in ponds, lakes, seas, and rivers. Thus, the likelihood of cross contamination of leeches in these kinds of environments by high intensities of $\mathrm{HMs}$ is not insignificant.

Metals bioaccumulation in aquatic organisms is formidably impacted by metals concentrations in the external environment. Various studies have been conducted on a wide range of aquatic creatures like fish (Rosli et al., 2018; Salam et al., 2019), crustaceans (Anual, et al., 2018; Zaleha et al., 2010), bivalves (Yuan et al., 2020) and gastropods (Gawad, 2018). Water quality and HMs levels have significant effects on the population density of medicinal leech (Sağlam et al., 2018). High levels of heavy metals were reported in the tissues of leeches (Chornaya et al., 2018; Wang et al., 2015). However, no comparable research works had been conducted on their saliva which has been demonstrated to have high therapeutic potentials. Hence, the current study intended to focus on the HMs concentrations in the sampled region and their bioaccumulation in a selected part of the leeches (tissues) and in their saliva extracts. The work also intended to examine the relationship between the HMs concentrations in leeches' saliva and the external ecological surroundings.

\section{Materials and Methods}

\section{Chemicals and Glassware}

All reagents and acids used were of AAS grade. Deionized - certified free of heavy metals - water was used to prepare different reagents. Concentrated $\mathrm{HNO}_{3} 65 \%$ was purchased from fisher scientific (UK), concentrated $\mathrm{HCl} 37 \%$ was purchased from Merck (Germany); nickel and zinc standards were purchased from Merck (Germany). All heavy metal standards were purchased from Perkin Elmer, USA. Certified standard reference materials DORM-4 was from National Research Council, Canada (NRC, Ottawa, Canada). Pre-cleaned and acidwashed glassware were used for all analyses. All glassware was soaked with $10 \% \mathrm{HNO}_{3}$ solution for 24 hours and rinsed thoroughly with de-ionized water prior to any use analysis (Khalid et al.,2016).

\section{Samples Collection and Preparation}

Leeches were gathered from Cheneh Lake, Terengganu, Malaysia (Figure 1) and instantly transported to the laboratory for more tests. Ambient water samples were gathered and saved in plastic containers following acidification at $\mathrm{pH}<2$ to diminish the precipitation of HMs or the absorption of metals into the container's walls before additional analysis (Uddin et al.,2016). The samples were stored at $+4^{\circ} \mathrm{C}$ before the analysis. An atomic absorption Spectrophotometer instrument model Perkin-Elmer Analyst 800 AAS was utilised for detecting zinc and nickel, whereas $\mathrm{Cd}, \mathrm{Cr}$, $\mathrm{Mn}, \mathrm{Fe}, \mathrm{Pb}$, Se were identified by utilising ICP-MS. To verify the accuracy and precision of the analytical method, analytical blanks triplicates and certified standard reference materials DORM-4 were used.

\section{Acid Digestion Method}

All samples were prepared by acid digestion using a digestion solution which comprises a mixture of concentrated $\mathrm{HNO}_{3} 65 \%$ and a concentrated $\mathrm{HCl} 37 \%$, in a ratio of (1:3) in $250 \mathrm{ml}$ beakers (Uddin et al., 2016). The digestion was completed by using water bath at $95^{\circ} \mathrm{C}$ for 8 hours.

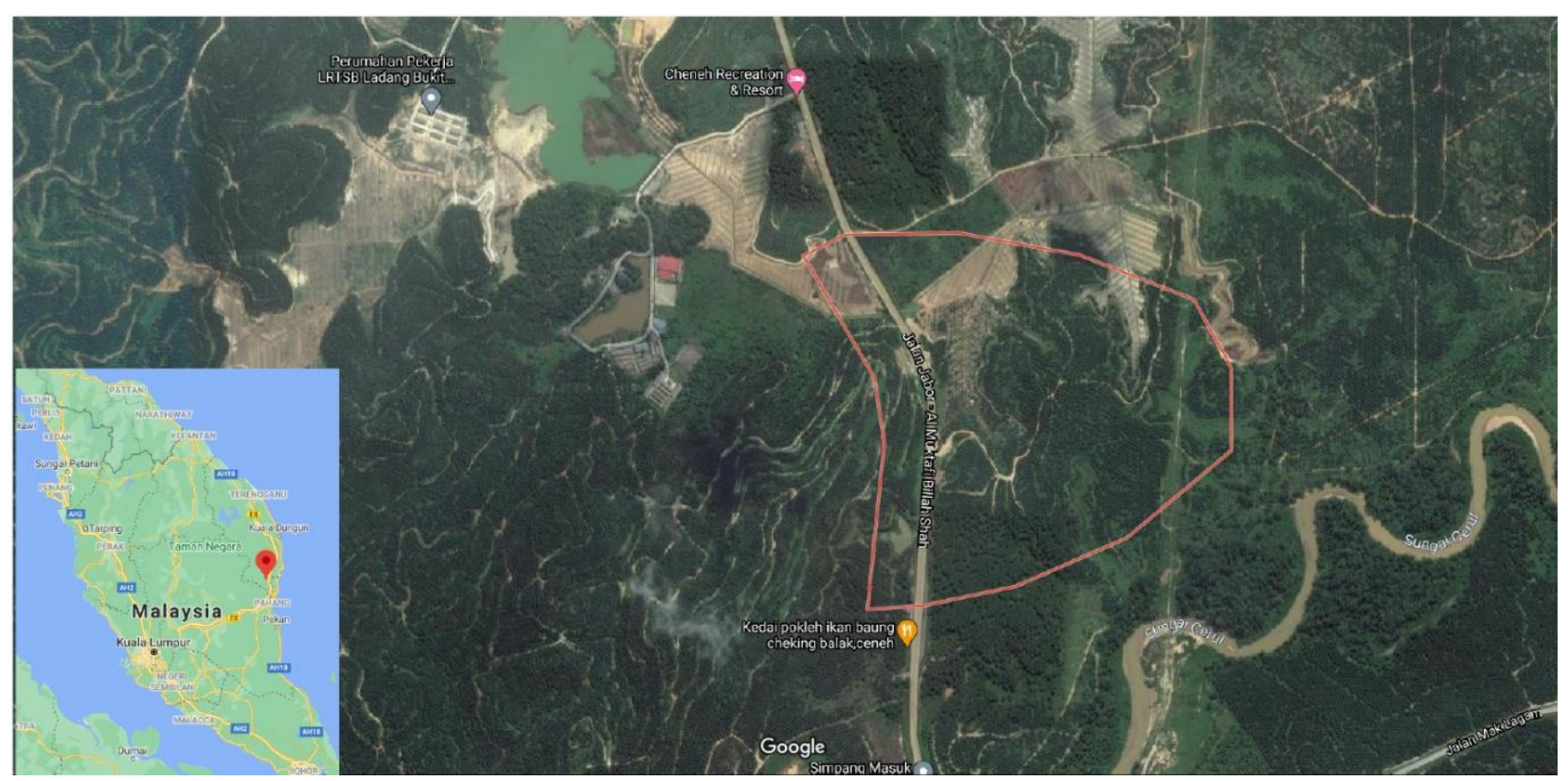

Figure 1. Leech sampling area (Cheneh, Terrenganu, Malaysia) 


\section{Sample Preparation}

Leech tissue (LT): 10 Frozen leeches $\left(-20^{\circ} \mathrm{C}\right)$ were thawed at room temperature and homogenized. $0.5 \mathrm{~g}$ of their tissues were dissolved in acid digestion solution.

Leeches' saliva extract (LSE): saliva was extracted following the standard method (Alaama et al., 2014). In brief 20 leeches were fed on a phagostimulatory solution comprising of sodium chloride $0.15 \mathrm{M}$ and Arginine $0.001 \mathrm{M}$ through a parafilm membrane. Once feeding process is completed, leeches are transferred to a falcon tube and immersed in ice for $15 \mathrm{~min}$, and then leeches were squeezed, and the saliva extract was collected. A volume of $10 \mathrm{ml}$ of the extracted saliva was used for digestion as stated above.

Lake water (LW): $10 \mathrm{ml}$ of water from the lake (LW) were digested as mentioned above.

\section{Effect of Maintaining Leeches in Controlled Conditions on the HMs Concentrations in Their Tissues and Saliva}

This part of the study aimed to investigate the alteration of the heavy metals concentrations in leeches' saliva by changing their external environmental conditions. Seventy leeches were placed in a covered plastic container with $10 \mathrm{~L}$ of water under $25 \pm 1^{\circ} \mathrm{C}$. Leeches were exposed to a 12 hours of dark / light cycle (Alaama et al., 2014). A washing method depending on changing leeches' habitat by using water with less concentration of heavy metals was introduced. Normal non-chlorinated tap water was used to maintain the leeches in the laboratory by changing the leeches' container water every three days.

In addition, deionised water was used to keep the leeches in order to examine the impact of this water on the HM concentrations as well as perform a comparison with normal water.

Every three days, the water used for keeping the leeches in the laboratory was changed and replaced with normal non-chlorinated tap water/deionized water. Post three weeks of normal water washing, leeches' tissue, leeches' saliva, and leeches' water samples were prepared and labelled as LTn, LSn and $\mathrm{LWn}$ respectively. Similarly, after three weeks of deionized water washing, leeches' tissue, leeches' saliva, and leeches' water samples were prepared and labelled as LTd, LSd and LWd respectively. All samples were prepared in triplicate to ensure lower error value.
The digested samples (tissues, saliva and water) were cooled at room temperature and filtered with a grade 1 Whatman filter paper in a volumetric flask, the filtered residues were washed twice with $10 \mathrm{ml}$ deionized water and filtered, their volumes completed to $50 \mathrm{ml}$ using deionized water, and finally transferred to a plastic containers maintained at $4^{\circ} \mathrm{C}$ until further analysis.

\section{Data Analysis}

Student $t$ test was performed to compare the mean heavy metal concentration in control (wild sample) with treated group (leeches under tap and deionized water). Tukey's post hoc test was used to identify homogenous groupings. A Pearson productmoment correlation was run to determine the relationship between the concentrations of heavy metals in Lake water, leech tissue and leech saliva. $P$ Value less than 0.05 was regarded statistically significant. All Statistical analyses were performed using the SPSS v.19 software package for Windows (SPSS Inc., USA).

\section{Results}

Table 1 shows the recoveries of analyzed certified standard reference materials DORM-4 using the developed analytical methods and digestion methods, all metals showed recovery between $86.15 \%$ - 98.02\%.

\section{Lake Water}

Concentration of HMs in the lake water are shown in table 2. Table 2 also displays the concentrations of HMs in tab water used for leech washing method and the concentration limits of heavy metals in surface water class II and class III according to INWQS.

The high concentrations of HMs observed in lake water was associated with high concentrations of HMs in both leeches' tissues and saliva Figure 2. A Pearson product-moment correlation was conducted to determine the relationship between the presence of heavy metals in lake water and leeches' tissues and saliva. There was a strong, positive correlation between the concentrations of heavy metals in lake water and leeches' tissues, which was statistically significant $(r=.984, n=8, P=.000)$, as well as between the

Table 1. Recovery of metals in standard reference materials.

\begin{tabular}{lccc}
\hline Element & Certified Value ppm & Reported Value ppm & Recovery\% \\
\hline $\mathrm{Cd}$ & $0.299 \pm 0.018$ & $0.268 \pm 0.024$ & 89.63 \\
$\mathrm{Cr}$ & $1.87 \pm 0.18$ & $1.62 \pm 0.26$ & 86.63 \\
$\mathrm{Mn}$ & $3.17 \pm 0.26$ & $3.02 \pm 0.18$ & 95.27 \\
$\mathrm{Ni}$ & $1.34 \pm 0.14$ & $1.18 \pm 0.21$ & 88.06 \\
$\mathrm{~Pb}$ & $0.404 \pm 0.062$ & $0.396 \pm 0.087$ & 98.02 \\
$\mathrm{Se}$ & $3.54 \pm 0.40$ & $3.05 \pm 0.30$ & 86.15 \\
$\mathrm{Fe}$ & $343.00 \pm 20.00$ & $311.68 \pm 31.25$ & 90.67 \\
$\mathrm{Zn}$ & $51.60 \pm 2.80$ & $48.50 \pm 3.60$ & 93.99 \\
\hline
\end{tabular}


Table 2. The mean concentration of heavy metals in lake and tap water.

\begin{tabular}{|c|c|c|c|c|c|c|c|c|}
\hline \multirow[b]{2}{*}{ Sample } & \multicolumn{8}{|c|}{ Means $\pm S D$} \\
\hline & $\mathrm{Cd}$ & $\mathrm{Cr}$ & $\mathrm{Mn}$ & $\mathrm{Ni}$ & $\mathrm{Pb}$ & $\mathrm{Se}$ & $\mathrm{Fe}$ & $\mathrm{Zn}$ \\
\hline Lake water & $5.40 \pm 0.13$ & $350.50 \pm 16.21$ & $33.48 \pm 1.429$ & $131.80 \pm 8.24$ & $34.15 \pm 0.31$ & $6.05 \pm 0.36$ & $1633.33 \pm 70.94$ & $2125.20 \pm 5.11$ \\
\hline Tap water & $2.02 \pm 0.03$ & $46.36 \pm 3.278$ & $10.15 \pm 0.132$ & $43.27 \pm 2.13$ & $26.31 \pm 1.44$ & $0.18 \pm 0.09$ & $865 \pm 13.23$ & $1285.23 \pm 21.15$ \\
\hline INWQS II & 10 & 50 & 100 & 50 & 50 & 10 & 1000 & 5000 \\
\hline INWQS III & 10 & 1400 & 100 & 200 & 20 & 250 & 1000 & 400 \\
\hline
\end{tabular}

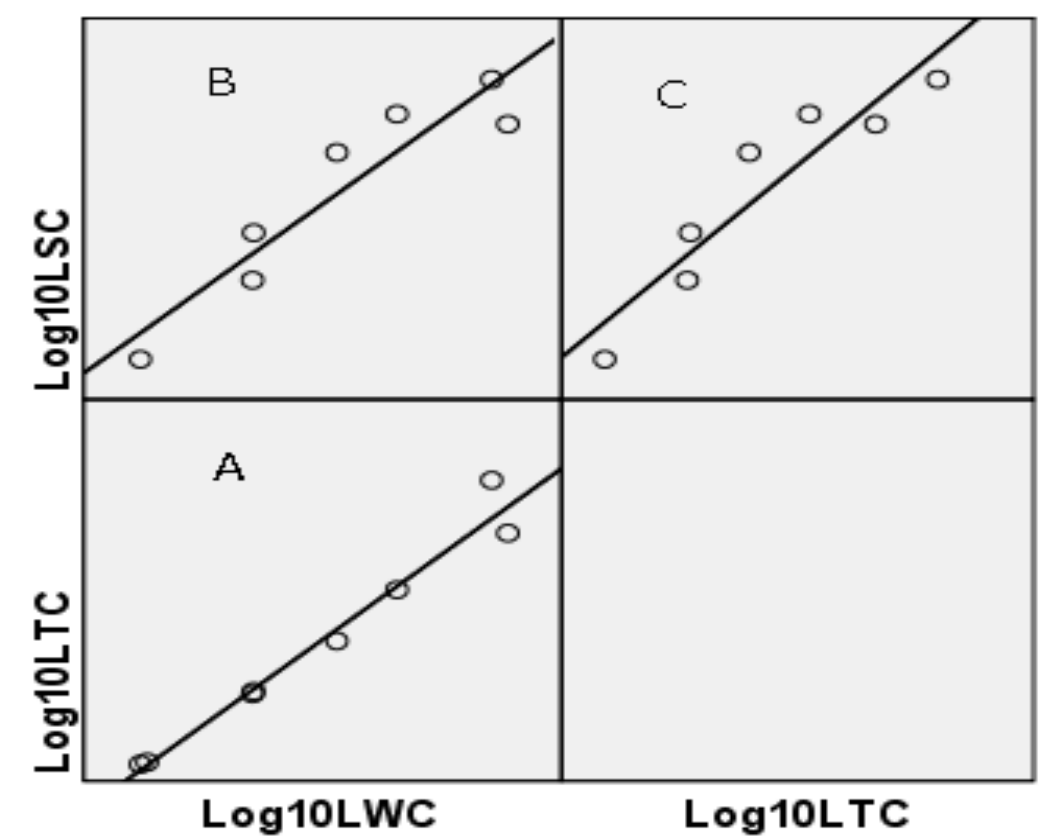

Figure 2. Scatter plots showing the regression analysis between heavy metals concentrations in lake water, leeches' tissues, and leeches' saliva.

Note: A, B, C regression analysis between heavy metals in lake water and leeches' tissues, Lake water and leeches' saliva and leeches' tissues and saliva consequently.

concentrations of heavy metals in lake water and leeches' saliva ( $r=.938, n=7, P=.002)$. Pearson correlation has also showed a clear positive correlation between the concentrations of heavy metals in leeches' tissues and leeches' saliva $(r=.932, n=7, P=.002)$.

\section{Leeches' Tissues}

Table 3 shows considerable amounts of HMs in leeches' tissues. It also shows the heavy metals concentrations after three weeks of successive washing with normal/deionized water. Statistical analysis showed significant reduction of heavy metal levels in the leeches' saliva in treated groups compared to the control $(\mathrm{P}<0.05)$

\section{Leeches' Saliva}

Table 4 shows the HMs concentrations in the leeches' saliva of the control group and their concentrations after three weeks of successive washing of the leeches with non-chlorinated tap water / deionized water. Statistical analysis showed significant reduction of heavy metal levels in the leeches' saliva in treated groups compared to the control $(P<0.05)$.

\section{Discussion}

The HMs concentrations in the lake water (the nature habitats of leeches) were reported high against the baseline data on Malaysian Interim National Water Quality Standards (INWQS) (Huang et al., 2015) and hence the habitat is classified as highly contaminated.

Substantial traces of HMs were observed in leech saliva extract. However, compared to the nontreated group, a considerable reduction in the concentrations of HMs was detected in leech saliva extracts from the treated groups $(P<0.05)$. To date, no similar studies were conducted before and hence the current report would cause a substantial effect on nurturing awareness on the public health sector and the impact would aid in evading likely metal toxicity in leech therapy. Studies have clearly shown anticancer properties of whole leeches' saliva extract (Merzouk et al., 2012), and hence it is vital to generate saliva extract free from toxic HM prior to administration to humans. In this paper, it was clear that the concentrations of HMs in the ambient environment impacted the concentrations of HM in the saliva. With successive water exchange, all studied HMs concentrations were seen to reduce. 
A higher concentration of HMs is also present in leeches' tissues when compared with the saliva extract. A strong positive correlation was found between the tissues of leeches and the HMs concentration in the lake water. However, with successive washing by using nonchlorinated tap water or deionized water, the HMs concentration in the water lowered, resulting in subsequent decreases in the concentrations of $\mathrm{HMs}$ in leeches' tissues. In this study, the metals accumulation by leeches' tissues was like other leech species (Chornaya et al., 2018; Wang et al., 2015) as well as the various freshwater organisms (Rosli et al., 2018; Anual, et al., 2018; Yuan et al., 2020).

These days, in the cosmetic field, the leeches' entire body is used to prepare creams and ointments by disregarding the fact that there could be toxic HM traces that may affect the skin (Arshad et al, 2020; Mohiuddin, 2019). For instance, arsenic, cadmium, and lead are classified as class I elemental impurities (Zaidi., 2010) and it is recommended for any medicine to be free from those metals or contain the level prescribed by Food and Drug Administration (FDA).

\section{Conclusion}

This study has shown that the leeches collected from North east coast of peninsular Malaysia (Terengganu) are polluted with heavy metals and hence not ready for immediate application on patient skin. Unfortunately, the medical use of leeches in Malaysia and southeast Asia in general lacks to authorities' control. Leech therapy is categorised under traditional practice and thus local uneducated persons perform these therapies in noncontrolled, nonsterile places. Furthermore, some people practice self-leech treatment in rivers where leeches are present, and they would immerse their feet in water in order to allow leeches to suck the blood. However, a majority of those employing leeches in traditional medicine think that the benefit pertaining to leeches is limited to 'sucking out the bad blood'. In fact, it is known that a crucial part of the leech therapy is what leeches inject back to our bodies. Unfortunately, leeches do not always inject useful materials only, but also harmful materials including bacteria and -based on this study- heavy metals. It is a known fact that majority of the aquatic organisms ingested by humans are contaminated with $\mathrm{HM}$, which sometimes could be at a higher level versus the reported values in this study. But what makes leeches different is that leeches and leeches' saliva have a direct contact with human blood vessels which enables them to infuse harmful heavy metals directly into the blood and cause the damage. Employing the washing procedure or controlling leeches' ambient habitat would considerably aid in minimising the concentration of metals in their saliva as well as the tissues.

\section{Ethical Statement}

No applicable.

\section{Funding Information}

This research was funded by Research Management Centre (RMC), IIUM under Endowment B grant scheme (Project ID: EDW B 10-0393) and grant no. SP11-003- 0071 from Malaysian Ministry of Finance. We extend our sincere gratitude to International Islamic University Malaysia for providing infrastructural facility throughout the research period.

Table 3. The mean concentrations of heavy metals in tissues of leeches and the changes of concentration before and after washing.

\begin{tabular}{|c|c|c|c|c|c|c|c|c|}
\hline \multirow{2}{*}{ Sample } & \multicolumn{8}{|c|}{ Means $\pm S D$} \\
\hline & $\mathrm{Cd}$ & $\mathrm{Cr}$ & $\mathrm{Mn}$ & $\mathrm{Ni}$ & $\mathrm{Pb}$ & $\mathrm{Se}$ & $\mathrm{Fe}$ & $\mathrm{Zn}$ \\
\hline$\overline{\mathrm{LT}}$ & $153.33 \pm 0.57$ & $12933.33 \pm 288.67$ & $916.33 \pm 7.02$ & $3512.00 \pm 116.80$ & $980.00 \pm 11.27$ & $162.33 \pm 4.16$ & $208660 \pm 2310$ & $54400 \pm 303$ \\
\hline LTn & $136.00 \pm 2.00$ & $8080.00 \pm 111.35$ & $371.00 \pm 3.00$ & $1889.00 \pm 70.80$ & $844.33 \pm 6.81$ & $134.00 \pm 6.55$ & $194670 \pm 2080$ & $22900 \pm 210$ \\
\hline$\uparrow \downarrow \%$ & 11.30 & 37.52 & $59.51^{*}$ & $46.21^{*}$ & 13.84 & 17.45 & 6.71 & $57.90^{*}$ \\
\hline LTd & $73.32 \pm 4.16$ & $6680.00 \pm 69.28$ & $353.00 \pm 2.32$ & $947.00 \pm 3.06$ & $74.67 \pm 0.97$ & $104.30 \pm 12.75$ & $46603 \pm 50$ & $23300 \pm 240$ \\
\hline$\uparrow \downarrow \%$ & 52.17 & $48.35^{*}$ & $61.47 * *$ & $73.03 * *$ & $92.38 * *$ & 35.74 & $77.65^{* *}$ & $57.16^{*}$ \\
\hline
\end{tabular}

Note: LT: leeches' tissues before washing, LTn: leeches' tissues after washing with non-chlorinated tap water, LTd: leeches' tissues after controlled washing, $\uparrow \downarrow \%$ : decrease / increase percentage. SD was calculated based on three individual replicates. ${ }^{*}=\mathrm{P}<0.05^{\prime}$ and $\left.{ }^{\prime * *}=\mathrm{P}<0.001\right)$. Significant level was tested at $95 \%$ confidant interval.

Table 4. The mean concentration of heavy metals in saliva of leeches and the changes of concentration before and after washing

\begin{tabular}{|c|c|c|c|c|c|c|c|c|}
\hline \multirow{2}{*}{ Sample } & \multicolumn{8}{|c|}{ Means $\pm S D$} \\
\hline & $\mathrm{Cd}$ & $\mathrm{Cr}$ & $\mathrm{Mn}$ & $\mathrm{Ni}$ & $\mathrm{Pb}$ & $\mathrm{Se}$ & $\mathrm{Fe}$ & $\mathrm{Zn}$ \\
\hline LS & $2.44 \pm 0.05$ & $568.33 \pm 11.54$ & $14.16 \pm 0.18$ & $241.80 \pm 4.93$ & $40.65 \pm 0.13$ & ND & $1228 \pm 11$ & $455.00 \pm 5.00$ \\
\hline LSn & $0.21 \pm 0.01$ & $239.50 \pm 2.96$ & $5.31 \pm 0.10$ & $130.85 \pm 1.77$ & $10.31 \pm 0.03$ & ND & $580 \pm 86$ & $425.00 \pm 10.00$ \\
\hline 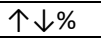 & $91.42^{* *}$ & $57.85^{*}$ & $62.06^{*}$ & $45.88^{*}$ & $74.62^{* *}$ & ND & $52.78^{*}$ & 6.59 \\
\hline LSd & $0.01 \pm 0.01$ & $244.66 \pm 14.11$ & $9.15 \pm 0.10$ & $40.06 \pm 0.97$ & $2.95 \pm 0.01$ & ND & $472.00 \pm 9.00$ & $420.00 \pm 5.00$ \\
\hline 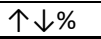 & $99.70^{* *}$ & $56.94^{*}$ & 35.41 & $83.42^{* *}$ & $92.73^{* *}$ & ND & $61.56^{*}$ & 7.69 \\
\hline
\end{tabular}

LS: leeches' saliva before washing, LSn: leeches' saliva after washing with unchlorinated tap water, LSd: leeches' saliva after controlled washing, $\downarrow \uparrow \%$ decrease / increase percentage. ND: lower than detection limit. SD was calculated based on three individual replicates. ${ }^{\prime *}=\mathrm{P}<0.05^{\prime}$ and $\left.{ }^{\prime * *}=\mathrm{P}<0.001\right)$. Significant level was tested at $95 \%$ confidant interval. 


\section{Author's Contribution}

M.A. conception and design of the work, data analysis and interpretation and manuscript preparation; A.M.G., A.M. and A.B.M.H funding acquisition and project administration; M.A., A.M.A and R.S.K manuscript preparation and revision. All authors have read and approved the manuscript.

\section{Conflict of Interest}

The authors declare that they have no known competing financial interests or personal relationships that could have appeared to influence the work reported in this paper.

\section{Acknowledgement}

The authors would like to thank Faculty of Science, International Islamic University Malaysia for providing the ICP-MS service. We extend our sincere gratitude to International Islamic University Malaysia for providing infrastructural facility throughout the research period.

\section{References}

Abdualkader, A. M., Ghawi, A. M., Alaama, M., Awang, M., \& Merzouk, A. (2013). Leech therapeutic applications. Indian journal of pharmaceutical sciences, 75(2), 127.

Ahmad, N., Jaafar, M. S., Nasir, T., \& Rafique, M. (2018). Determination of radon concentration and heavy metals $(\mathrm{Ni}, \mathrm{Pb}, \mathrm{Cd}, \mathrm{As}, \mathrm{Cr})$ in drinking and irrigated water sampled from Kulim, Malaysia. International Journal of Radiation Research, 16(3), 341-349.

DOI: 10.18869/acadpub.ijrr.16.2.341.

Alaama, M., AbdualKader, A. M., Mohammad, A., \& Merzouk, A. (2011). Isolation and Analytical Characterization of Local Malaysian Leech Saliva Extracts. IIUM Engeneering Jurnal, 12(4), 51-59. DOI: 10.31436/iiumej.v12i4.182.

Alaama, M., Helaluddin, A. B. M., Mohammad, A., Merzouk, A., Abdualkader, A. M., \& Awang, M. (2014). Starvation time and successive collection effects on leeches saliva collection quantity and proteins quality and quantity in wet season. Sains Malaysiana, 43(11), 1693-1697.

Anual, Z. F., Maher, W., Krikowa, F., Hakim, L., Ahmad, N. I., \& Foster, S. (2018). Mercury and risk assessment from consumption of crustaceans, cephalopods and fish from West Peninsular Malaysia. Microchemical journal, 140, 214-221. https://doi.org/10.1016/j.microc.2018.04.024.

Arshad, H., Mehmood, M. Z., Shah, M. H., \& Abbasi, A. M. (2020). Evaluation of heavy metals in cosmetic products and their health risk assessment. Saudi Pharmaceutical Journal, 28(7), 779-790. https://doi.org/10.1016/j.jsps.2020.05.006.

Basheer, A. O., Hanafiah, M. M., \& Abdulhasan, M. J. (2017). A study on water quality from Langat River, Selangor. Acta Scientifica Malaysia (ASM), 1(2), 1-4. DOI:10.26480/asm.02.2017.01.04.

Chornaya, L., Kovalchuk, L., \& Mikshevich, N. (2018). Seasonal bioaccumulation of heavy metals by medicinal leech Hirudo verbana. Hydrobiological Journal, 54(5). DOI: 10.1615/HydrobJ.v54.i5.60.
EPA. (2009). National Primary Drinking Water Regulations U.S Environmental Protection Agency. Washington D C.

Gawad, S. S. A. (2018). Concentrations of heavy metals in water, sediment and mollusk gastropod, Lanistes carinatus from Lake Manzala, Egypt. The Egyptian Journal of Aquatic Research, 44(2), 77-82. https://doi.org/10.1016/j.ejar.2018.05.001.

Huang, Y. F., Ang, S. Y., Lee, K. M., \& Lee, T. S. (2015). Quality of water resources in Malaysia. Research and Practices in Water Quality, 3, 65-94. DOI:10.5772/58969.

Khalid, R. S., Helaluddin, A. B. M., Alaama, M., Abdualkader, A. M., Kasmuri, A., \& Abbas, S. A. (2016). Reliability of graphite furnace atomic absorption spectrometry as alternative method for trace analysis of arsenic in natural medicinal products. Tropical Journal of Pharmaceutical Research, 15(9), 1967-1972. DOI: 10.4314/tjpr.v15i9.22.

Karadede, H., \& Ünlü, E. (2000). Concentrations of some heavy metals in water, sediment and fish species from the Atatürk Dam Lake (Euphrates), Turkey. Chemosphere, 41(9), 1371-1376. https://doi.org/10.1016/S00456535(99)00563-9.

Masindi, V., \& Muedi, K. L. (2018). Environmental contamination by heavy metals. Heavy metals, 10, 115132.

Merzouk, A., Ghawi, A., Abdualkader, A., Abdullahi, A., \& Alaama, M. (2012). Anticancer Effects of Medical Malaysian Leech Saliva Extract (LSE). Pharm Anal Acta S, 15, doi:10.4172/2153-2435.S15-001.

Mishra, S., Bharagava, R. N., More, N., Yadav, A., Zainith, S., Mani, S., \& Chowdhary, P. (2019). Heavy metal contamination: an alarming threat to environment and human health. In Environmental biotechnology: For sustainable future (pp. 103-125). Springer, Singapore.

Mohiuddin, A. K. (2019). Heavy Metals in Cosmetics: The Notorious Daredevils and Burning Health Issues. American Journal of Biomedical Science \& Research, 4(5), $332-337$. DOI: 10.34297/AJBSR.2019.04.000829.

Porshinsky, B., Saha, S., Grossman, M., Beery II, P., \& Stawicki, S. (2011). Clinical uses of the medicinal leech: A practical review. Journal of postgraduate medicine, $57(1), 65$. DOI: 10.4103/0022-3859.74297.

Rados, C. (2004). Beyond bloodletting: FDA gives leeches a medical makeover. FDA consumer, 38(5), 9.

Rosli, M. N. R., Samat, S. B., Yasir, M. S., \& Yusof, M. F. M. (2018). Analysis of heavy metal accumulation in fish at Terengganu coastal area, Malaysia. Sains Malaysiana, 47(6), 1277-1283. DOI: 10.17576/jsm-20184706-24.

Sağlam, N., Özbay, Ö., Demir, T., Balcı, M., Pala, A., \& Kılıç, A. (2018). Effect of Water Quality on Monthly Density Variation of the Endangered Southern Medicinal Leech Hirudo verbana Carena, 1820 (Hirudinea: Arhynchobdellida: Hirudinidae). Acta Zoological Bulgarica, 70, 433-441.

Salam, M. A., Paul, S. C., Noor, S. N. B. M., Siddiqua, S. A., Aka, T. D., Wahab, R., \& Aweng, E. R. (2019). Contamination profile of heavy metals in marine fish and shellfish. Global Journal of Environmental Science and Management, 5(2), 225-236. DOI: 10.22034/gjesm.2019.02.08.

Shuhaimi-Othman, M., A.K. Ahmad and E.C. Lim, . (2009). Metals concentration in water and sediment of bebar peat swampy forest river, Malaysia. Journal of Biological Sciences, 9, 730-737. DOI: 10.3923/jbs.2009.730.737. 
Singh, S. K., \& Rajoria, K. (2019). Medical leech therapy in Ayurveda and biomedicine-A review. Journal of Ayurveda and integrative medicine, 11(4), 554-564. https://doi.org/10.1016/j.jaim.2018.09.003

Sivachandran, P., Marimuthu, K., Ravichandran, M., \& Arockiaraj, J. (2013). Antibiotic susceptibility of body surface and gut micro flora of two aquatic leech species (Hirudinaria manillensis and Hirudinaria javanica) in Malaysia. Journal of Coastal Life Medicine, 1, 52-56.

Sulaiman, F. R., \& Hamzah, H. A. (2018). Heavy metals accumulation in suburban roadside plants of a tropical area (Jengka, Malaysia). Ecological Processes, 7(1), 1-11. https://doi.org/10.1186/s13717-018-0139-3.

Uddin, A. H., Khalid, R. S., Alaama, M., Abdualkader, A. M., Kasmuri, A., \& Abbas, S. (2016). Comparative study of three digestion methods for elemental analysis in traditional medicine products using atomic absorption spectrometry. Journal of analytical science and technology, 7(1), 1-7. https://doi.org/10.1186/s40543016-0085-6

Wang, W., Yang, Y., Xiaona, L., \& Meng, L. (2015). Residue Analysis on Heavy Metals in Medicinal Leeches. World
Science and Technology-Modernization of Traditional Chinese Medicine (9), 1890-1892.

Yuan, Y., Sun, T., Wang, H., Liu, Y., Pan, Y., Xie, Y., ... \& Fan, Z. (2020). Bioaccumulation and health risk assessment of heavy metals to bivalve species in Daya Bay (South China Sea): Consumption advisory. Marine Pollution Bulletin, 150, 110717.

https://doi.org/10.1016/j.marpolbul.2019.110717

Yunus, K., Zuraidah, M. A., \& John, A. (2020). A review on the accumulation of heavy metals in coastal sediment of Peninsular Malaysia. Ecofeminism and Climate Change, 1(1): 21-35. DOI: 10.1108/EFCC-03-2020-0003

Zaidi., K. (2010). >232<Elemental Impurities Limits. Pharmacopeial Forum 36(1).

Zaleha, K., Kamaruzzaman, B., John, B. A., \& Ong, M. (2010). $\mathrm{Cd}, \mathrm{Cu}$ and $\mathrm{Pb}$ concentration levels in horseshoe crab nesting grounds of pahang coast, Malaysia. Journal of Biological Sciences, 10: 790-794.

DOI:10.3923/jbs.2010.790.794. 